Душко М. Ковачевић

Универзитет у Новом Саду

Филозофски факултет

Одсек за историју

profesorkovacevic@gmail.com
Оригинални научни рад

примљено: 25. јун 2011

прихваћено: 1. октобар 2011

\title{
СПОЉНА ПОЛИТИКА РУСИЈЕ ОД КРИМСКОГ РАТА ДО ПОЧЕТКА ВЕЛИКЕ ИСТОЧНЕ КРИЗЕ (1856-1875)*
}

Сажетак: Еволуција спољне политике Русије после Кримског рата била је условљена како неопходношћу реформи у самој земљи тако и измењеним околностима у међународним односима. Русија је морала да „обезбеди предах после изгубљеног рата за спровођење унутрашњих реформи", али у исто време морала је да тражи и начин да изађе из „опасног и понижавајућег положаја” у који ју је довео Париски мировни уговор. Било је потребно да земља изађе из међународне изолације, у којој се нашла пред антируском „кримском коалицијом” европских држава.

Руска дипломатија је остварење својих задатака у Европи постигла прво путем зближења са Француском, а када се то показало неуспешним, са Пруском. Први корак у зближењу са Пруском учињен је у време устанка у Пољској 1863. године, да би 1871. године, после пораза Француске, Русија искористила погодан тренутак и дипломатским средствима, уз подршку Пруске, добила измену чланова Париског уговора који су ограничавали њена права у Црном мору.

Тај успех био је такође „купљен" великом ценом, пристанком на уједињење Немачке под вођством Пруске, што је суштински изменило прилике у Европи, а самим тим и положај Русије. Поставило се после тога питања осигурање западних граница земље, настала је потреба за тражењем нових савезника ради обезбеђења позиције земље у међународним односима. Прво је нађен излаз у зближавању са Немачком и Аустроугарском, у форми Савеза три цара. Али, тај „консултативни пакт“ конзервативних држава показао се недовољно постојаним, због противречности интереса његових чланица у Европи и на Балкану.

Кључне речи: Русија, Француска, Пруска, Париски конгрес, пољски устанак, крај неутралности Црног мора, Савез три цара.

\section{Приближавање Француској}

Император Русије Никола I, „који никада није боловао”, умро је почетком марта 1855. године од грипа. „Има основа да се каже да је узрок смрти Николе I био 
у непосредној вези са неуспехом у Кримском рату”. Умирући, Никола I се кајао пред својим наследником. „Предајем теби моје заповедништво, на жалост, не у оном поретку како сам желео, остављам много тешкоћа и брига". ${ }^{1}$ Поразом у Кримском рату Русија није „изгубила статус велике државе”, али је њен међународни положај ослабио. Париски мировни уговор закључен 30. марта 1856. године био је понижавајући за Русију. Уговор је потврдио пораз Русије и тиме, између другог, нанео удар и њеном утицају на Балкану. За Русију су посебно тешки били чланови уговора који су се тицали Црног мора. Одредба о неутрализацији Црног мора забрањивала је Русији да у његовим водама држи флоту, гради утврђења и инфраструктуру. Конвенција о режиму пловидбе мореузима потврђивала је ,древно право" Турске (Османског царства), да у време мира онемогући војним бродовима страних држава пролазак кроз Босфор и Дарданеле. Али у време рата у којем би учествовала Турска, султан је могао да „пропусти флоте држава својих савезника”, што је представљало опасност за безбедност југа Русије. Протекторат Русије над Влашком и Молдавијом и њено право да штити хришћане у Турској замењени су колективном гаранцијом шест европских држава, учесница Париског конгреса. Русија је тиме изгубила право на легалну подршку националним покретима балканских народа. Губитком Јужне Бесарабије, Русија је ,лишена контроле ушћа Дунава”. У корист Турске на Кавказу морала је да се одрекне Карса, који је у рату освојила, мада јој је заузврат враћен Севастопољ. Погоршан је и положај Русије на Балтику, због демилитаризације Аландских острва. Поред тога, уговором између Велике Британије, Француске и Аустрије, Турској је гарантована независност и територијални интегритет, чиме је створена „кримска коалиција” . Русија је тиме била принуђена да се одрекне своје раније улоге у Европи. Променио се и однос снага на континенту, па је водеће место уз Велику Британију, чији је утицај знатно ојачао, заузела Француска. Савезнички односи Петрограда и Беча раскинути су у рату, јер је Аустрија била на страни руских противника. Уз то Русија није могла да се поузда ни у Пруску, која је у сукобу са европским државама била уздржана, чиме се земља нашла у пуној дипломатској изолацији. Цар Александар II, који је 1855. године наследио Николу I, ,делио је у многоме погледе свога оца”, али је за разлику од њега био свестан да се мора мењати спољна политика. Нови цар је схватао да се са Кримским ратом ,завршила цела једна епоха у историји Русије”, те да је потребно „потражити своје место у координатама нових међународних односа”. ${ }^{2}$

Радост после смрти Николе I била је општа. Професор Петроградског универзитета, историчар Константин Кавелин, писао је 4. марта 1855. године у Москву свом колеги професору Тимофеју Грановском: „Калмицки полубог, прошао је ураганом, бичем и рашпом руском државом у протеклих 30 година, ... уништио је хиљаде карактера и умова ... Ако време које долази не би било тако страшно и

\footnotetext{
* Рад је настао као фазни резултат републичког пројекта број 177002 под називом Војвођански простор $у$ контексту европске историје.

${ }^{1}$ М. Гелер, История Российской империи, Т. ІІІ, Москва 1997, 75.

${ }^{2}$ Сборник договоров России с другими государствами 1856-1917 г2., Москва 1956, 23-41; Н. С. Кинямина, Внешняя политика России второй половины ХІХ в., Москва 1974, 12-14; История внешней политики России. Вторая половина ХІХ века, Москва 1997, 49-50; М. Гелер, нав. дело, 76-77.
} 
тмурно, будућност тако тајанствена и загонетна, можда би с ума сишли од радости и опили се од среће”. Будућност је за Русију била „тајанствена и загонетна”, страх је изазивао и нови цар. Била је позната његова приврженост крепосном праву, као и његова „наслеђена страст према војним парадама”. Алексеј Хомјаков убеђивао је своје пријатеље славенофиле да ће нови цар бити реформатор. Основу свог оптимизма он је црпео у историјском искуству Русије. У концепцији Хомјакова био је присутан и рационални моменат, који је произлазио из чињенице да је "нови цар отпочињао своју владавину са обавезом да поправи очајно стање земље, које је добио у наследство". У писму цару Александру II, Константин Аксаков настојао је да окарактерише стање духа у Русији: „Сви лажу један другога, увиђају то и продужавају да лажу, неизвесно је до чега ће то довести". То очајно стање земље које је у наслеђе оставио Никола I, поставило је пред руску владу и Министарство спољних послова неопходност промена, "што је захтевало нове методе деловања и нове људе". Цар је знао да су земљи неопходне унутрашње реформе, које су се могле остварити само ако на границама завлада мир, што је захтевало да се у спољној политици предузимају „опрезна и одмерена решења", а спољнополитички спорови решавају једино дипломатским средствима. Већина државних делатника Русије била је са тим сагласна. Министар спољних послова и канцелар К. В. Неселроде, који је „служио царевима а не држави“, на крају дипломатске каријере истицао је, да је неопходно да се земља окрене „својим унутрашњим пословима и моралном и материјалном развитку”. Указивао је да је дотадашња спољна политика готово занемарила властите националне интересе, због „опште европских, а искуство указује да би убудуће спољна политика морала да произилази из националних интереса“. ${ }^{3}$

За новог министра спољних послова и наследника канцелара Неселродеа цар је именовао кнеза Александра Горчакова, „човека... који је, за разлику од свог претходника, имао властите погледе на задатке спољне политике Русије”. Горчаков је представљао „нови тип дипломате", који је тежио да односе међу државама не гради ,превасходно на династичким, већ на политичким и економским везама". Нови министар отпочео је рад у крајње сложеним околностима, у међународној изолацији и економској заосталости, када је Русији било важно да, како је говорио Горчаков, „залечи ране”. „У садашњем положају наше државе у Европи, ... главна пажња Русије мора да буде усмерена на наш унутрашњи развитак и сва спољна политика треба да је подређена том задатку". Пензионисање Неселродеа и постављање Горчакова за министра „означило је одлучан заокрет“ у спољној политици Русије. Општи правац руске спољне политике формулисан је у Горчаковљевој циркуларној депеши од 2. септембра 1856. године, упућеној руским дипломатским представницима у европским престоницама. Белешку о политичким односима Русије, саставио је у фебруару 1856. године барон Неселроде. Било је то завештање дипломате, који се тридесет година налазио на челу Министарства спољних послова Руске империје. Пораз у Кримском рату убедио је једног од архитеката Свете алијансе у неодложност окретања "унутрашњим пословима" и

\footnotetext{
${ }^{3}$ С. С. Татищев, Император Александар II. Его жизнь и царствование, Москва 2006, 111-112, 115.
} 
одрицање од сваке "спољне делатности", која би то могла да угрози. „Мир, закључен у Паризу најављује почетак нове политичке ере. Узнемиреност услед жестоких борби, замењују односи, пуни узајамних добрих намера“. Управо тај правац у спољној политици одобрио је Александар II, пошто му је Горчаков, после преузимања министарске дужности, изложио њен концепт. Политика Русије, наглашавао је Горчаков, мора се водити у сопственом интересу, али „не на штету других”. „Кажем, Русија се љути. Не Русија се не љути, она се усредсређује”. Русија je, дакле, требало да „сабира своје снаге и концентрише своје напоре на унутрашњи опоравак“, а да се истовремено уздржава од „активног уплитања у европске послове“. Горчаков је желео да истакне мирољубиве намере своје земље, али је упозоравао да то не искључује њено активно учешће у међународним односима. Основни спољнополитички задатак Русије после Кримског рата тицао се измене одредаба Париског уговора о неутрализацији Црног мора и успостављања изгубљених позиција на Балкану. Тако је пораз у Кримском рату показао не само слабост земље већ је одредио још "уже поље деловања Русије - Европу", Балкан, где је она могла да рачуна на савезништво православног становништва. ${ }^{4}$

„Усредсређивање” које је Горчаков поставио у средиште руске спољне политике, подразумевало је „неопходан предах за успостављање пређашње снаге“, али оно није потрајало дуго. Задатак „повратка моћи и престижа империје" могао се остварити само уз помоћ савезника, међутим, „тражење савезника увлачило је Русију у сложен систем међународних односа“. О избору будућег савезника није било јединственог мишљења - цар је тежио споразуму са Пруском, а Горчаков са Француском, којој је нагињало и јавно мњење. Према Аустрији Горчаков се односио непријатељски, а савез са Пруском сматрао је недовољним за обнову утицаја Русије у Европи. Цар Александар II је, у тренутку „када су државни интереси превагнули над осећањима династичке солидарности", коначно подржао Горчакова, који је после тога изјавио да „међу правим савезницима ми видимо само Француску”. Горчаков је схватио да би савез са Француском, која је била „главни арбитар у Европи после 1856" , означио рушење „кримске коалиције". Тако се у потрази за савезником Русија окренула Француској, која је била "иницијатор и главни њен противник на Криму". Жељу за приближавањем показао је и Париз, за обе земље заједнички интереси били су очигледни. Приближавање Русије и Француске имало је основа у супарништву са Великом Британијом, као и заједничким интересима на Балкану. Прихватање Горчаковљевог плана представљало је остварење његове замисли исказане 1856. године, да ће се Русија зближити са Француском. „У Источном питању ми ћемо се приближити Француској, рачунамо на њу као на противтежу нашим противницима“. Руска влада се надала да ће приближавањем Француској ослабити свог највећег супарника Велику Британију, уз то савез је отварао за Русију и перспективу слабљења „кримске коалиције”, те поништавања одредбе Париског уговора о Црном мору. Оправданост Горчаковљевог плана, као да

\footnotetext{
${ }^{4}$ С. С. Татищев, нав. дело, 182-183; Н. С. Киняпина, нав. дело, 13-14; К. В. Нарочницкая, Россия $u$ отмена нейтрализаииий Ченого моря 1856-1871 г2., Москва 1989, 8-9; История внешней политики России, 52-54; М. Гелер, нав. дело, 114.
} 
је потврђивао и програм француског цара Наполеона III, који је намеравао да прошири границе своје државе и учврсти њену хегемонију у Европи. Наполеон III је планирао да Француској припоји Савоју, Ницу и леву обалу Рајне. Да би тај план остварила, Француска је морала да се суочи са Аустријом и да неутралише утицај Велике Британије, а за то јој је био потребан савез са Русијом. У исто време политичка подршка принципу народности коју је прокламовао Наполеон III, те жеља да се ослабе вишенационална царства Аустријско и Турско, одговарали су и интересима Русије. ${ }^{5}$

Први корак у зближавању две државе учинио је Наполеон III, који је на крунисање Александра II послао свог поверљивог саветника Морнија, присталицу савеза са Русијом. Морни је у Петроград стигао у августу 1856. године, као нови француски посланик. На „достојанственом и ласкавом“ пријему у Петергхофу, цар се Морнију обратио речима: „Ја вас радо видим овде... Ја сам веома захвалан цару Наполеону и никада нећу заборавити његову благонаклоност према нама током преговора [у Паризу]“. Истовремено је у Париз на место посланика упућен гроф Кисељев са намером да успостави „срдачне и поштене“ односе, који је уз то подржавао замисао Горчакова о савезу Русије и Француске. Морни и Кисељев почели су одмах са припремама плана о зближавању две државе, што је омогућило да у зиму 1856-1857. године и у Петрограду и у Паризу отпочну тајни преговори о будућем савезу. Упоредо са дипломатском делатношћу, текло је обнављање економских и трговинских веза. Било је сасвим извесно да је преостао још само корак до заједничког циља, стварања савезничких односа две земље. Као први виднији корак у остварењу плана о савезу требало је да послужи посета царевог брата великог кнеза Константина Николајевича Паризу у пролеће 1857. године. Уочи рата са Аустријом Наполеон III је настојао да разјасни став руске владе, према француском плану о анексији Савоје и Нице. Наполеон III се надао да ће добити подршку Русије за присаједињење италијанске територије Француској, па је као знак добре воље понудио Русији компензацију у Галицији. План је изложен великом кнезу Константину, али он није пристао да разматра то питање - сматрао је да је опасно подржавати намере Наполеона III јер би то могло да увуче Русију у нови војни сукоб. Посета великог кнеза Константина Паризу била је први корак у зближавању два двора, други је требало да представља сусрет двојице царева. ${ }^{6}$

Ипак, „коначна реч у преговорима припадала је владарима", стога је било договорено да се они сретну у Штутгарту. Наполеон III није скривао забринутост за судбину француско-енглеског савеза, плашио се да би приближавање Русији могло да доведе до кварења односа са Великом Британијом уз чију подршку је Француска вратила своје место у Европи. У разговору са Кисељевом Наполеон то није скривао, када је рекао: „Ја мислим да је за очување поретка, за безбедност Француске, за status quo,... савез са Енглеском нужан. Друго је питање када је неопходно одлучно

\footnotetext{
5 Архив внешней политики Российской империи (даље АВПРИ), ф. Канцелярия, Отчет министра иностранных дел за 1856 г., л. 26; W. E. Mosse, The Rise and Fall of Grimean system 1855-1871, London 1963, 50-105; М. Гелер, нав. дело, 122-123.

${ }^{6}$ С. С. Татищев, нав. дело, 184, 188; История внешней политики России, 54-55.
} 
деловање, када мислимо да мењамо карту Европе, тада и само тада нужан је савез са Русијом. До тог тренутка ми треба да останемо само добри другови и да не идемо даље. Од свега је најважније да живимо у споразуму са свима, а посебно са Енглеском“. Горчаков је знао за ту дилему француског цара када је рекао да „са једне стране Француска тежи ... пуном споразуму са нама, а са друге жели да избегне раскид са Енглеском". Енглеска влада је, у намери да осујети рускофранцуско зближавање, упозорила Париз да би Русија тиме желела да обезбеди подршку за заузимање Цариграда. Наполеон III није делио то мишљење, пошто је његово приближавање Петрограду имало за циљ да спречи стварање савеза Русије, Пруске и Аустрије, који би превасходно био уперен против Француске. Наполеон III је пред пут у Штутгарт поставио пред француску дипломатију један далекосежан задатак, који се тицао промене уговора из 1815. године и стварања нове карте Европе. Руска дипломатија није имала јасан и конкретан план деловања, већ је на сусрет царева гледала као на могућност да проникне у намере друге стране. Додуше, Горчаков је са својим плановима упознао амбасадора у Паризу Павла Кисељева, када му је саопштио да „тражи човека који би му помогао да поништи чланове Париског уговора, који се тичу црноморске флоте и границе Бесарабије”. Такав човек је, по мишљењу Горчакова, могао да буде Наполеон III, који је тежио учвршћивању хегемоније Француске у Европи. Иако је Горчаков сусрету у Штутгарту придавао значај „историјског догађаја“, његове намере нису ишле даље од захтева за измену Париског уговора о неутрализацији Црног мора. ${ }^{7}$

Сусрет Александра II и Наполеона III у Штутгарту од 25. до 27. септембра 1857. године показао је целој Европи срдачне односе двојице дојучерашњих противника. Наполеон III је током тих разговора изнео план о преуређењу Европе, који се првенствено тицао италијанског питања. Намеравао је да сазна шта Русија мисли о његовој помоћи Италији у борби против Аустрије. Русија је била спремна да подржи Француску, али је захтевала промену члана Париског уговора о неутралности Црног мора. Учесници састанка су се сагласили о неопходности међусобне координације у питањима спољне политике. Уједно су се обавезали да „неће учествовати ни у једном од крупних европских питања, а да се претходно међусобно не посаветују". Али, разговори о Пољској изазвали су прве међусобне несугласице. На изјаву Наполеона да између Француске и Русије стоји ,јједно питање око кога се не могу сагласити", цар Александар је после разговора љутито рекао „Са мном се усудио да говори о Пољској“. Због тога или због узрока који су се тицали поништења Париског уговора споразум није био потписан. Усаглашена су само акта која су се тицала „другостепених питања“, о пловидби мореузима и државном уређењу Дунавских кнежевина. Мада није донео никакве конкретне резултате, сусрет у Штутгарту представљао је ипак корак ка поновном учвршћивању утицаја Русије у Европи. Наполеон III је, наиме, пристао да две државе на Балкану делују заједнички. После Кримског рата Источно питање је и даље играло значајну улогу у спољној политици Русије, мада је сада она морала да

\footnotetext{
${ }^{7}$ АВПРИ, ф. Канцелярия, Отчет министра иностранных дел за 1857 г., л. 8, 18; Н. С. Кинямина, нав. дело, 17-18.
} 
делује много опрезније. Оцењујући пристанак Наполеона III на заједничко деловање на Балкану, Горчаков је писао: „Француска је проценила значај подршке Русије..., али је схватила да на њу може да рачуна под условом да помогне руску владу на Истоку”. Међутим, Александар II био је знатно мањи франкофил од свог министра спољних послова. Цара је онеспокојавала италијанска политика Наполеона III, у Петрограду су на Италију гледали као на жариште револуције. Син цара Николе I давао је предност Пруској и Аустрији, без обзира на њену непостојаност. Али, било је, ипак, очигледно да би савез са Француском помогао Русији да поврати део изгубљеног престижа на Балкану. ${ }^{8}$

Да би показала да је променила спољну политику, Француска је одлучила да подржи Русију као заштитника балканских народа, пре свега Срба и Румуна. Рускофранцуска сарадња онемогућила је 1858. године Турску да силом успостави суверенитет над Црном Гором. Интервенција Русије и Француске присилила је Турску да прекине војне операције и пристане на разграничење са Црном Гором. Заједничко деловање двеју држава предупредило је и аустријско мешање у унутрашње ствари Србије 1858. године, у време преврата и повратка династије Обреновића. Највећи успех постигнут је у Румунији 1857. године, када је Аустрија морала да повуче трупе из Влашке и Молдавије. Потом су на Париској конференцији 1858. године проширена аутономна права румунских кнежевина, а у јануару 1859. године Русија и Француска подржале су избор Александра Кузе за владара Влашке и Молдавије. Султан је 1861. године био принуђен да да̂ сагласност на стварање јединствене владе Дунавских кнежевина чиме је, захваљујући сарадњи Русије и Француске, отпочео процес стварања независне румунске државе. ${ }^{9}$

Развој догађаја на Балкану уверио је Петроград у исправност политике савеза са Француском. За Наполеона III, који се у то време припремао за рат против Аустрије у Италији, била је изнад свега важна подршка Русије. "Одсуство формалног споразума" са Русијом спутавало је Наполеона III да отпочне рат против Аустрије. Наполеон III је иступајући заједно са Русијом на Балкану рачунао да ће задобити њену подршку у рату са Аустријом. Од великих европских држава једино је Русија била вољна, у тренутку када је Наполеон објавио циљ рата „Италија, слободна од Алпа до Јадрана!“, да подржи Француску у решењу италијанског питања. Наполеон III је стога предузео мере у циљу постизања споразума са Петроградом. Русија је с друге стране желела да се ослободи одредаба Париског уговора, због чега је била спремна да „жртвује оно што је раније бранила". Посредством руског дипломате Кисељева, Наполеон III је покушао да сазна какву ће позицију заузети Русија у случају рата. После закључења споразума са Кавуром у Пломбијеру у јулу 1858. године, о "заједничком иступу против Аустрије", француски цар је сматрао да је наступио тренутак за договор са Русијом. Француског цара је додатно охрабрила посета Паризу великог кнеза Константина, па је у септембру 1858. године послао у Варшаву свога брата од стрица принца

\footnotetext{
${ }^{8}$ С. С. Татищев, нав. дело, 190, 194-195.

${ }^{9}$ В. Н. Виноградов, Россия и обьединение румынских княжеств, Москва 1961, 28-39.
} 
Жерома. Наполеон III је посредством Жерома настојао да увери руску владу да ће се рат водити не само у интересу Француске и Италије већ и Русије, чиме би Петрограду дао могућност да Аустрији ,супротстави Словене”. Пошто је знао за приврженост Александра II Пруској, Наполеон је цару указао на могућност стварања тројног руско-француско-пруског савеза „који би помрачио славу Аустрије”. За Горчакова је пресудна била француска подршка измени одредбе Париског уговора, због чега је настојао да преговоре са Француском држи отворене. У Петроград је после тога француска влада послала пројекат будућег уговора, у коме је предлагала да Русија заузме став „благонаклоне неутралности и да пошаље војску према аустријској граници” и „тиме одвуче њене снаге са италијанског ратишта”. Русија је требало да изврши притисак и на друге државе Немачког савеза, да их на тај начин задржи од отвореног иступања против Француске. Подршка Француске Русији у односу на измену Париског уговора и овога пута је изостала, у предлогу уговора дато је само обећање да ће Париз о томе утврдити коначан став месец дана пре објаве рата. ${ }^{10}$

Као што је Француска избегавала да се изјасни о најважнијем питању за Русију, тако је и званични Петроград настојао да избегне све обавезе које би могле да увуку земљу у рат и „доведу до европског пожара”. Због тога је за руску владу француски предлог, о прекиду дипломатских односа са Аустријом био неприхватљив и она је одбила да о њему преговара. Влада у Петрограду је и поред договора са Наполеоном III настојала да очува добре односе са Пруском и Аустријом. Горчаков није искључивао могућност да у будућем францускоаустријском рату Пруска подржи Аустрију. Ту дилему изразио је крајем новембра 1858. године, у писму принцу Жерому: „Ако ми будемо иницијатори ... непријатељства према Аустрији, да ли можемо рачунати да Немачка неће стати на њену страну”. Горчаков тиме није желео да прекине преговоре са Француском, али је одбио да прихвати услове „чије испуњење је претило увлачењем Русије у европски рат". Пошто је изостала подршка Француске измени одредбе Париског уговора о Црном мору, пројекат уговора није могао да задовољи руску владу. Понуда Француске да осигура потпору Русији за присаједињење Галиције била је за Горчакова неприхватљива. Горчаков је то категорички одбио, када је изјавио да је „Русији довољна њена територија”. ${ }^{11}$

Преговори су после тога били прекинути, да би у децембру 1858. године Француска иступила са новим предлозима. Наполеон III је ублажио раније захтеве према Русији и настојао да од ње добије пристанак да ће "на својој граници везати значајне аустријске војне снаге". Иако су се цар Александар II и министар Горчаков плашили да би упућивање војске на аустријску границу могло да доведе до рата, били су одлучни да прихвате ризик; њихов услов је био да се у пројекат уговора

\footnotetext{
${ }^{10}$ История внешней политики России, 56-57.

${ }^{11}$ Р. И. Рыжова, Сближение России с Франции после Кримской войны и русско-франиузкий договор 3. марта 1859 г. Учены записки МГУ им. В. П. Потемкина, Т. XXVIII, Вып. 4, Москва 1959, 146-157, 160168; История внешней политики России, 57.
} 
укључи јасна подршка Француске за измену Париског уговора. Русија је дакле била спремна или да се обавеже на очување неутралности, или, пак, да на границу са Галицијом упути "војне снаге довољне да вежу 150.000 аустријских војника". Заузврат од Наполеона III је тражено да пристане да приликом закључења мира „употреби сав лични утицај да анулира чланове Париског уговора, који су ограничавали руске поморске снаге у Црном мору и да постави питање уступања Бесарабије Молдавији”. Наполеон III је одговорио Горчакову да је „дужан да поштује већ раније преузете уговорне обавезе, па га стога ни нови договори не могу ослободити од њих". ${ }^{12}$

Пошто су предлози једне и друге стране били познати, даље преговоре око закључења уговора водили су француски министар спољних послова Валевски и амбасадор Кисељев. Руски дипломата је био свестан чињенице да је његовој земљи потребан мир, страховао је да би измена појединих чланова Париског уговора могла да изазове „протесте других европских држава и да доведе до рата”. Кисељев је сматрао да је за његову земљу боље да се „наоружа стрпљењем” и да до даљег не изазива нове заплете, већ да са Француском закључи уговор који Русију не би превише обавезивао. Александар II за кога је Париски уговор био „вечити кошмар” и Горчаков којем је циљ било његово поништење, одлучили су и поред резервисаности Наполеона III према руском захтеву да прихвате споразум са Француском. Тако је Русија пристала да 3. марта 1859. године закључи са Француском уговор, који су у Паризу потписали Валевски и Кисељев. Русија се сагласила да сачува „благонаклону неутралност” према Француској, у време њеног рата са Аустријом. Прихватила је, такође, да утиче и на очување неутралности других европских држава. Обавезе Француске биле су "сасвим неодређено дефинисане", Париз се, додуше, сагласио да се о измени важећих уговора који се тичу обе земље, тиме и Париског уговора, расправља у тренутку закључења мира. Александар II је после тога пристао да ради олакшања француских ратних операција "упути војску према аустријској граници". ${ }^{13}$

Показало се да је споразум био повољнији за Француску, пошто је предупредио стварање аустро-пруско-енглеског савеза. Русија није добила ни територијалне компензације, ни чврсте гаранције Француске за измену одредаба Париског уговора о Црном мору. Али, и поред тога не може се одрећи његов значај за Русију, споразум јој је омогућио да изађе из међународне изолације. Само постојање савеза „са првом државом Европе” подигло је ауторитет Русије, док је посредно „представљало потврду њене снаге и утицаја”. Руско-француски уговор утицао је истовремено и на захлађење односа између Француске и Велике Британије, што није промакло Горчакову: „Одустајање од уговора значило би ... поновно гурање цара Наполеона у загрљај Енглеске. Прошлост нам је тачно показала какве из тога могу да произађу последице”. Упркос клаузули о тајности и одрицању обе стране да он постоји, споразум није остао непознат. Аустрија је

\footnotetext{
12 А. Л. Нарочницкий, Международные отношения и внешняя политика России от Парижского (1856 г.) до Франкфуртского мира, Москва 1946, 3-13.

${ }^{13}$ Сборник договоров России с другими государствами 1856-1917, 69-70.
} 
покушала да се у последњем тренутку приближи Русији, нудећи јој „споразум у питањима Истока”. Бечки двор је послао у Петроград грофа Карољија, али је Александар II, који још није опростио Аустрији држање у време Кримског рата, одбио понуђене преговоре. ${ }^{14}$

У рату 1859. године Русија је указала Француској знатну дипломатску подршку, чиме је онемогућила Пруску и друге државе, чланице Немачког савеза, да се умешају у сукоб. Горчаков је 27. маја 1859. године упутио циркуларну ноту руским дипломатским представницима акредитованим на немачким дворовима, у којој се изјаснио против њихове евентуалне војне подршке Аустрији. Да би умирио чланове Савеза, Горчаков их је уверавао како му је француска влада потврдила да „нема никаквих непријатељских намера према Немачкој". Иако је то представљало несумњиву подршку Француској, Наполеон III је ипак био незадовољан, у првом реду због чињенице да Русија није упутила војску на границу Галиције и тиме онемогућила слање појачања аустријској армији у Италију. После пораза Аустрије, отпочели су у јулу 1859 . године у Вила Франки мировни преговори. Наполеон III и Франц Јозеф били су сагласни да Аустрија уступи Сардинији Ломбардију, али да задржи Венецију. Несигуран у држање Пруске Наполеон је настојао да од грофа П. А. Шувалова сазна да ли би Русија објавила Пруској рат у случају да она крене против Француске. Шувалов му је, међутим, одговорио „ни зашта на свету“. Руске захтеве Наполеон III није ни поменуо, али је рат ипак био од користи за Петроград. Уздрмао је „кримску коалицију” и створио предуслове за руско деловање на Балкану, мада је наговестио и непостојаност руско-француског споразума. Томе је свакако допринела и чињеница да Француска није намеравала само да очува своје интересе на Балкану, већ није желела да због Русије квари односе са Великом Британијом. Због тога је и подршка Наполеона III балканској политици Русије била ограничена и недоследна, што је њену дипломатију уверило да не може озбиљно да рачуна на заједничко деловање са Француском. Држањем Француске био је незадовољан и цар Александар, који је у октобру 1859. године, приликом сусрета са Кисељевом у Варшави признао: „Моје поверење у политичке погледе Луја Наполеона, страшно је поколебано“. Када је потом гроф Кисељев представио цару пројекат "формалног уговора" са Француском, Александар II је на њему написао: "Против кога?" Тиме се дошло до суштинске промене, у односима Русије и Француске. Додуше то још није био прекид у међусобним односима, али је Француска престала да буде главни руски савезник - „њено место заузела је Пруска“. 15

Крајем 1859. и почетком 1860. "дошло је до нових немира међу хришћанским становништвом Балкана", што је подстакло Горчакова да "иступи са низом нових иницијатива". Могућности руске политике на Балкану, међутим, биле су „омеђене оквирима” Париског уговора. Горчаков је стога настојао да путем преговора регулише односе Русије и Турске и тиме осигура покровитељство над

\footnotetext{
${ }^{14}$ Сборник договоров России с другими государствами 1856-1917, 69-70; Н. С. Кинямина, нав, дело, 2122; Л. И. Нарочницкая, нав. дело, 35-36.

${ }^{15}$ С. С. Татищев, нав. дело, 200-202.
} 
хришћанима. Политика Горчакова имала је за циљ да подигне престиж Русије међу балканским народима, да тиме покаже европском јавном мњењу да без ње не може „да буде решено ниједно важно питање на Истоку”. Подржавајући принцип очувања status quo-a на Балкану, она је настојала да одржи „,антиосманске покрете” и поред тога што се цар Александар II прибојавао "да се на Истоку не закува каша". Амбасадор Кисељев је у преговорима са Наполеоном III добио његов пристанак за заједничко деловање, ради „очувања мира на Балкану”. На тражење савеза са Паризом утицала је и чињеница да је Француска имала готово пресудан утицај у Турској, о чему је Игњатијев писао: „представник Француске има одлучујућу реч... на Истоку, све се дешава уз његову сагласност“. У међувремену је заједничка интервенција Петрограда и Париза присилила Турску да у августу 1862 . године закључи мир са Црном Гором. Иступом Русије и Француске заустављено је потом продубљавање сукоба Србије и Турске у јуну 1862. године. Али, већ од 1863. године отпочела је „нова етапа у балканској политици Русије”. После погоршања односа са Француском због устанка у Пољској, Русија не само да је изгубила њену подршку на Истоку већ је одлучила да истраје у намери да „искључи мешање европских држава у односе између Турске и њених хришћанских поданика”. У инструкцији Николају Игњатијеву, који је 1864. године наименован за амбасадора у Цариграду, Горчаков је упозоравао: „Ваше постављење треба да симболизује добре намере Русије и жељу да следи конзервативну, а не револуционарну политику на Истоку”. Под „конзервативном политиком”, Горчаков је подразумевао обазривост у односима „према национално-ослободилачким покретима хришћанских народа и очување status quo-a на Балкану". Ослабљена у Кримском рату Русија се прибојавала могућег распада Турске, сматрала је да се тиме могу окористити друге европске државе. Горчаков је то у извештају Александру II недвосмислено истицао, када је упозоравао, „,наши интереси обавезују нас да не убрзавамо њен крај”. ${ }^{16}$

Положај хришћана у Турској постао је такорећи стална тема разговора Наполеона III, његовог министра спољних послова Тувнела и руског амбасадора Кисељева. Горчаков је још увек рачунао да ће успети да придобије Француску за своје планове, па је од Кисељева захтевао да предложи влади у Паризу заједнички споразум о Балкану. Предлог Горчакова је у плановима француског цара добио другу конотацију, пошто је он желео да један такав споразум прошири и на италијанско питање. Замисао Наполеона III била је да Аустрији као компензацију за изгубљену Венецију уступи територије на обали Јадранског мора. Кисељеву је наложено да саопшти француској влади да је „предложена замена немогућа”. И поред овог новог неуспеха Горчаков се није одрекао плана да придобије и остале државе, да заједничким притиском и без француске подршке натерају Турску на реформе у својим европским провинцијама. Наиме, Горчаков је 16. маја 1860. године приликом сусрета са представницима великих европских држава у Петрограду, указао на неопходност да се учини крај хаотичном стању у Турској.

\footnotetext{
${ }^{16}$ С. С. Татищев, нав. дело, 199-200; Н. С. Кинямина, нав. дело, 41-42; Международные отношения на Балканах 1856-1878 г2., Москва 1986, 28-31, 56-65; История внешней политики России, 63-65.
} 
Затим је упутио циркулар руским дипломатским представницима акредитованим на европским дворовима, у коме је указао на неопходност споразума са Портом ради поправљања положаја хришћана. У циркулару је упозоравао да се „може догодити да Европа буде обележена као саучесник у одржавању за њих тако несносног стања“. Истовремено је Горчаков од Кисељева захтевао да од француског двора затражи пристанак на уговор који би потврдио савез између Француске и Русије у свим важнијим питањима, па тиме и у Источном. Међутим, уговор није био потписан, руска влада се коначно уверила у непоуздност савеза са Паризом. Горчакову је преостало само да констатује да је подршка Француске за Русију била „неискрена и сасвим ограничена”. Пресудну улогу у хлађењу руско-француских односа одиграо је сусрет руског цара Александра II са пруским краљем Фридрихом Виљемом и аустријским царем Францом Јозефом у октобру 1860. године у Варшави.

\section{Варшавски сусрет царева \\ Пољски устанак и приближавање Пруској}

Русија је после неуспешног савеза са Француском, променила спољнополитичку оријентацију и одлучила да ослонац за своју политику потражи у Пруској и Аустрији. И Аустрија је после пораза у Италији настојала да заборави све противречности које су је удаљавале од Русије, у првом реду на Балкану, и да отпочне политику приближавања две државе. Русија је такође била спремна да „опрости” непријатељско држање Аустрије у време Кримског рата. Први корак на зближавању учинио је лично Александар II, који је поручио цару Францу Јозефу: „Ми нисмо злопамтила”. Приближавању две до јуче супротстављене државе допринело је свакако и хлађење односа између Аустрије и Пруске. Али, Пруска је овога пута настојала да осујети руско-аустријско приближавање, тако што би Русији понудила споразум о савезу. Тај задатак био је поверен Оту фон Бизмарку, кога су у Русији „примили као посланика рођачког двора“ уз све „званиче почасти и церемоније". Током три године проведене у Петрограду, Бизмарк је својим деловањем ,дубоко укоренио и на Двору и у јавном мњењу мисао" да је Пруска искрени пријатељ и поуздани савезник Русије. Аустријски цар је такође желео да разјасни ставове Русије и Пруске па је, посредством посланика у Бечу Балабина, предложио цару Александру II да се лично састану у Варшави. Горчаков је у међувремену обавестио Наполеона III да они не долазе у Варшаву „да би тамо створили коалицију већ примирје" и да никакав савез против Француске није могућ „зато што то неће Русија“. Циљ Горчакова био је да тиме предупреди не само зближавање Француске и Велике Британије већ да је привуче на „сарадњу са сва три двора". Иако Наполеон није одбацио могућност таквог споразума, сматрао је да би претходно требало сачекати резултате сусрета три цара у Варшави. ${ }^{17}$

Цареви су боравили у Варшави од 22. до 26. октобра 1860. године, а централно место у разговорима било је посвећено потреби јединственог деловања

\footnotetext{
${ }^{17}$ АВПРИ, ф. Канцелярия, Отчет министра иностранных дел за 1861 г., л. 64-64 об; С. С. Татищев, нав. дело, 203-206, 213-214.
} 
влада трију земаља у „борби против револуционарних покрета”. Франц Јозеф је означио Француску као земљу из које је долазио најснажнији подстицај за такве покрете, при чему је упозорио да она жели да подстакне револуцију не само у Италији већ и у Угарској и Пољској. Да би се томе стало на пут, аустријски цар је предлагао закључење споразума упереног против Француске. И Пруска, која је истакла своје претензије на леву обалу Рајне, била је незадовољна политиком Француске. Русија је покушала да ублажи ставове Аустрије и Пруске када је Александар II изјавио „да Русија не жели да се веже споразумом усмереним против француских интереса“, већ да тежи „општеевропском јединству влада”. Истога мишљења био је и кнез Горчаков, који је сматрао да Русија и поред тога што „нема никаквих илузија о карактеру политике цара Наполеона" жели очување добрих односа са Француском. Сусрет царева је ипак показао да препрека приближавању Русије и Аустрије није била Француска већ антируска политика Беча на Балкану. Горчаков о томе није имао илузија: ,,у Србији, Црној Гори и Херцеговини политика коју спроводи Аустрија непријатељска је за Русију”. ${ }^{18}$

Сусрет у Варшави није донео нека конкретна решења, био је то у ствари само покушај да се сазна мишљење друге стране. Ипак, три године касније, у време пољског устанка, показали су се резултати. Било је потребно, како је писао Кисељев, да се приликом сусрета утврде добри односи са Аустријом и Пруском, те да се означе претпоставке заједничког деловања уколико то буде потребно. Али, то није било довољно уверљиво за француску владу која је, пред опасношћу од стварања руско-аустријско-пруске коалиције, настојала да заинтересује Русију за успостављање „трајнијих пријатељских односа”. Француски министар спољних послова Тувнел је, после сусрета у Варшави, предложио основе „поверљивог споразума" Француске и Русије. Пројекат француске владе садржао је предлог о италијанском и Источном питању ,која су била од интереса за обе стране“. Русија је словом уговора требало да призна, сматрали су у Паризу, новонастало стање у Италији, то јест присаједињење Савоје и Нице Француској. Тако су обавезе Русије биле сасвим јасно утаначене, док Француска у питању Истока "није на себе ништа преузела".

И поред тога руска влада није сасвим одбацила предлог о споразуму, јер је сматрала да он може да послужи као основа за неке будуће разговоре. Наполеон III је, међутим, одустао од даљих преговора, сматрао је да Француска мора да има „одрешене руке у односима према немачким државама и Великој Британији”. Руска дипломатија је, дакле, после сусрета у Варшави намеравала да води политику на два колосека, да очува добре односе са Француском и отпочне приближавање Аустрији и Пруској. Краткотрајно приближавање Француској, до чега је дошло због српскотурског сукоба 1862. године, није могло да измени основни правац руске спољне политике која је била усмерена ка Пруској. Последице тога морао је да осети и министар спољних послова Горчаков, када је у влади почело отворено да се говори о његовом погрешном спољнополитичком усмерењу земље. У октобру 1862. године

\footnotetext{
${ }^{18}$ АВПРИ, ф. Канцелярия, Отчет министра иностранных дел за 1861 г., л. 64-64 об; С. С. Татищев, нав. дело, 203-206, 213-214.
} 
смењен је дотадашњи посланик у Паризу П. Д. Кисељев, наследио га је А. Ф. Будберг, присталица савеза са Пруском. Тако су руско-француски односи незадрживо ишли силазном путањом, да би током пољског устанка 1863. године потпуно захладнели. Устанак у Пољској поново је Русију супротставио државама које су чиниле „кримску коалицију" . У Француској су сви били на страни устаника, Велика Британија је такође била на страни Пољака. Лондон је уз то сматрао да ће устанак ослабити Русију и да ће, неминовно, довести до прекида њених односа са Француском. Устаници су уз то уживали и подршку Аустрије, иако је она 1846. године жестоко угушила покрет Пољака у Галицији. Али, ниједна од њих није намеравала да Пољацима пружи „реалну помоћ". Уз то и делатност Бизмарка, током његове посланичке службе у Петрограду, била је усмерена против уређења рускопољских односа, што се може објаснити чињеницом да су "добри односи између Руса и Пољака водили учвршћивању руско-француских веза”.

И овога пута се показало, да је поновно учвршћивање позиција Русије у Европи било тешко и мукотрпно. Када је 22. јануара 1863. године избио устанак у руском делу Пољске, Русија је доведена пред нова искушења. Горчаков је с правом указивао, да су се „политички интереси у тој години суочили у Пољској. То питање било је камен спотицања за све државе”. Догађаји у Пољској показали су да ће Русија имати највише проблема са Француском, за разлику од Пруске чије је држање ишло наруку руској влади. Канцелар Бизмарк предузео је енергичне мере да би онемогућио ширење устанка на западни део пољских земаља. Бизмарк се руководио жељом да онемогући обнову независне Пољске, а као главни спољнополитички циљ Пруске одредио је заједничко деловање са руском владом. При томе је рачунао да ће поред стицања наклоности цара Александра II, онемогућити закључење руско-француског савеза. Бизмарк је стога истицао да је гушење устанка у интересу Пруске, „није реч само о руској политици, нити о нашим односима према Русији, већ о односу Пруске према Пољском питању,... ако она [Русија] буде постојан савезник Пруске против других држава,... Познањ и Данциг остају у пруским рукама“. Потом је ту своју мисао пророчки обликовао: "Између Француске и нас никада неће бити мира, са Русијом никад неће бити неопходан рат, под условом да прилике не измене либералне глупости и династичке апсурдности". Да би успоставио пуну сарадњу са владом у Петрограду, Бизмарк је у Русију послао генерала Густава фон Алвенслебена са овлашћењем да сачини договор о заједничком деловању у Пољској. Тиме је отворен пут за закључење тајне конвенције о сарадњи у гушењу устанка, која је и потписана у Петрограду 8. фебруара 1863. године. Конвенција је омогућавала начелницима генералштабова руске и пруске војске да ради „успостављања поретка и спокојства” указују једни другима узајамну помоћ, а „у случају неопходности да пређу границу, да би се супротставили устаницима који би прешли из једне земље у другу”. Бизмарк је 
после тога могао са правом да закључи да је „Конвенција... била успешан шахмат пешака, који је омогућио да се добије партија“. ${ }^{19}$

Горчаков је сматрао да је конвенција "непотребна и опасна” по Русију, мада није могао да се супротстави прусофилским осећањима цара који је у споразуму са Пруском видео потврду „монархистичке солидарности”. Показало се да је Горчаков био у праву, јер је потписивање конвенције погоршало односе са европским државама и појачало антируско расположење у Француској и Великој Британији. Споразум Русије и Пруске дао је тако основа државама западне Европе, да покушају да пољском питању дају међународни карактер. Енглеска влада је тежила не само да поквари односе Русије и Француске, већ и да допринесе слабљењу међународних позиција Петрограда. Горчаков је то добро уочио и означио је Велику Британију, као носиоца антируске кампање у Европи: „све се своди на Енглеску. Да ли ће се она устремити на Исток у Европу,... у целини мир је угрожен ради обнове Пољске”. Иако су и у Бечу са благонаклоношћу гледали на такав став Велике Британије, ипак нису отворено иступили против Русије због страха да се устанак не прошири и на

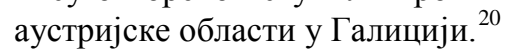

Енглеска влада је у међувремену одлучила да у вези са пољским питањем упути 12. марта 1863. године сопствени демарш којим је, позивајући се на одредбе Бечког уговора, предложила давање устава Пољској и захтевала амнестију за устанике. Пошто је изостао заједнички иступ три европске државе, Горчаков је то искористио и у Лондон упутио усмени приговор против таквог захтева. У лето 1863. године устанак је захватио готово целу Пољску, чиме се појавила опасност од нових заплета у Европи. Томе је свакако допринео и Наполеон III, који је "наизглед неочекивано иступио са пројектом о стварању независне Пољске". Наполеон III је сматрао да би то могла бити добра прилика за промену карте Европе, што би њему дало могућност да реализује сопствене планове. Предлог Наполеона III није подржан ни у Лондону ни у Бечу, али је нанео тежак ударац односима Француске са Русијом. Услед ширења устанка у Пољској, руска влада је поред примене репресивних мера била приморана и на уступке. Објавила је манифест о амнестији устаника, као и о административним реформама. Владини акти дошли су са закашњењем, услед чега нису могли да "предупреде колективно уплитање западних држава". Водећа улога у антируској кампањи у првој етапи устанка у Пољској припала је Великој Британији, којој је превасходни задатак био да посеје „,семе раздора" између Русије и Француске. ${ }^{21}$

Русији је 17. априла 1863. године упућена нота од стране Велике Британије, Француске и Аустрије, у којој се захтевало да предузме мере „ради прекида крвопролића у Пољској”. Тако је акција око Пољске била крајње непријатна за руску владу, она је по сваку цену тражила излаз. Петроград је стога деловао

\footnotetext{
${ }^{19}$ Bismark, Gedanken und Erinnerungen, Stuttgart-Berlin 1928, 213, 282; С. С. Татищев, нав. дело, 375-376; В. Т. Рувененков, Польское восстание 1863 г. и европейская дипломатия, Москва-Ленинград 1957, 122144; М. Гелер, нав. дело, 126.

${ }^{20}$ АВПРИ, ф. Канцелярия, Отчет министра иностранных дел за 1863 г., л. 81-82; История внешней политики России, 68-69.

${ }^{21}$ В. Т. Рувененков, нав. дело, 314-319.
} 
опрезно, али сасвим одлучно. Положај руске владе олакшали су донекле и сами пољски устаници, који су тражили укључење западних делова Белорусије и Украјине у састав Пољске. Такав захтев допринео је да се против устаника у Русији окрену и присталице компромиса. У исто време Горчаков је предузео и мере на дипломатском плану да би ојачао позиције Русије. У одговору свакој држави појединачно, настојао је да је увери да ће "руска влада спровести неопходне реформе" у Пољској. У ноти упућеној у Лондон Горчаков је тврдио да Русија "није нарушила одредбе Бечког уговора". Док је покушавао да стиша незадовољство званичног Лондона, према француској влади био је донекле оштрији. Указивао је да је управо Француска допустила да се на њеној територији припреми завера која је довела до устанка у Пољској. ${ }^{22}$

Наполеон III је знао да се у борбу против Русије не може упустити сам, због чега је настојао да на своју страну привуче Аустрију, којој је заузврат обећао подршку у питању уједињења Немачке. Влада у Бечу одбацила је понуду Наполеона III, била је свесна да би је то одвело у сукоб са Русијом. И поред подршке Пољацима у Лондону су страховали да би обновљена Пољска ступила у савез са Француском. Тиме би Француска постала најјача држава у Европи, што је Лондон донекле удаљавало од пољског питања. У Бечу су такође били свесни да би обнова Пољске представљала ,лош пример за словенско становништво Монархије”. На крају је постало јасно да због Пољске неће доћи до заплета у међународним односима. Али су и поред тога Велика Британија, Француска и Аустрија упутиле јула 1863. године поново ноту у Петроград. У ноти су предлагале спровођење реформи у Пољској, амнестију устаника, повратак „уставне повеље из 1815. године” и сазивање европске конференције представника држава учесница Бечког конгреса ради разматрања пољског питања. Горчаков је одговорио да је "пољско питање унутрашња ствар Русије", да она о њему може да разговара само са учесницима деобе Пољске, што је значило са Аустријом и Пруском. На тај начин су из разговора о Пољској биле искључене Француска и Велика Британија, али је укључена Пруска. У ноти руске владе од 7. септембра 1863. године посланицима у Лондону, Берлину и Бечу, Горчаков је обећао да ће руска влада учинити све да се поврати мир, али да она "прекида даље преговоре о Пољској са европским државама". Руска влада је знала је да између Велике Британије, Француске и Аустрије не постоји чврсто јединство, као и да ће оно са приближавањем краја устанка бити још слабије. ${ }^{23}$

Тиме се ,заштита” Пољака од западних држава „свела само на изливе незадовољства и на добре жеље”. Било је јасно да нико не жели да ратује да би обновио Пољску, тим пре што је руска војска под командом генерала Ф. Ф. Берга крајем 1863. и почетком 1864. године уништила и последње одреде устаника. Репресивне мере руске владе и наговештене реформе допринеле су неуспеху устанка у Пољској. Горчаков је после тога могао да у извештају цару напише да унутрашње тешкоће земље ,траже неодложно решење“ и да је стога нужно да се питања спољне политике потчине унутрашњим, због чега је „пре свега потребно

\footnotetext{
${ }^{22}$ В. Т. Рувененков, нав. дело, 127-135, 142-148; История внешней политики России, 69-70.

${ }^{23}$ Исто.
} 
подржати општи мир“. Међутим, крај пољског устанка значио је и ликвидацију споразума Русије и Француске, па је Петроград после раскида са Паризом морао да промени своју спољнополитичку оријентацију и да се приближи Пруској. После пољског устанка у Европи се оцртавао нови распоред снага, Француска се за Русију поново преобратила у противника, што је означило и крај настојања да се уз подршку Наполеона III промене одредбе Париског уговора о Црном мору. Русија се као и раније сучељавала и даље са Аустријом на Балкану, а са Великом Британијом у Централној Азији. Због тога је морала да потражи новог савезника у Европи, а осим Пруске „никога није било на видику“. У Кримском рату била је побеђена Русија, "ко је из њега изашао као победник постало је јасно кратко време после тога". Један од победника који је учествовао у рату био је Пијемонт, "који је постао стожер уједињења Италије". Други победник била је Пруска, „која није учествовала у рату, али јој је савез са Русијом помогао да створи немачку империју" . ${ }^{24}$

Пруска је била једина европска држава, која је подржала руску владу у њеној борби са пољским устаницима. Политика уједињења Немачке под вођством Пруске „гвожђем и крвљу” захтевала је, с Бизмаркове тачке гледишта, пријатељске односе са Русијом. У Петрограду су у то време постојале две спољнополитичке концепције. Једна, коју су заступали славенофили, а донекле и кнез Горчаков, била је ,антинемачки настројена”, а друга пронемачка, чији је "постојани поборник и у време зближења са Француском", био Александар II. Пруска и Аустрија представљале су „бедем спокојства“ у Европи, према њима је стога „ишла царева наклоност“. Спор око одређивања даљег смера руске спољне политике окончан је 1863. године, када је коначну „превагу однео немачки правац“. Петроградска конвенција потписана у фебруару 1863. године, била је за Бизмарка од знатне дипломатске користи. Пруска је добила као награду за Алвенслебенову конвенцију сагласност Русије на заузимање Шлезвига и Холштајна, две данске провинције. Горчаков је био категорички против, тврдио је да „никада Русија неће допустити, да Белт постане нови Босфор". Али, против воље цара он није могао и дански теснаци ће, у Првом светском рату, затворити руску флоту у Балтичком мору. ${ }^{25}$

Бизмарков програм уједињења Немачке спровођен је „одозго” под вођством Пруске, прве „жртве” постали су Шлезвиг и Холштајн. Тренутак после смрти данског краља Фридриха VII, који је умро 15. новембра 1863. године, чинио се повољан. Пруска је још четрдесетих година безуспешно покушала да их анектира, али су против тога иступиле готово све европске државе, па и Русија. Шездесетих година прилике су биле знатно повољније. Али, то ни тада није било „лако учинити“, како је касније говорио Бизмарк. „Сви су били против мене. Поједине личности на двору, Аустрија, мале немачке државе, Енглези који нису желели да у наше руке пређе Килски теснац. Са Наполеоном је требало начинити споразум јер је он желео да према њему преузмемо одређене обавезе... сви су они били против мене

\footnotetext{
${ }^{24}$ История внешней политики России, 70.

25 Л. И. Нарочницкая, Россия и войны Пруссии в 60-х годах за объединение Германии „сверху“, Москва 1960, 78-102; Н. И. Хитрова, Триумф А. М. Горчакова, Отмена нейтрализации Черного моря, у Российская дипломатия в портретах, Москва 1992, 211.
} 
и још многи други“. Да би предупредио евентуалне неспоразуме са европским државама, Бизмарк је Бечу предложио да заједнички војно интервенишу ради „ослобађања Немаца“ из херцогства Шлезвиг и Холштајн од Данске у тренутку када jе на престо ступио нови краљ Кристијан IX и када је усвојен нови устав, којим је озакоњено присаједињење Шлезвига Копенхагену. Канцелар је рачунао да ће „отпасти могућа коалиција европских држава против Пруске” уколико она буде иступала заједно са Аустријом. Пруски предлог против Данске прихваћен је у Бечу. $^{26}$

Бизмарк је у исто време желео да осигура и подршку Русије за рат против Данске који је, како је писао Миљутин, био „већ раније припремљен у његовим плановима у борби за уједињење Немачке”. Влада у Петрограду није имала могућност избора, јер је тада отпочела са освајањима у Централној Азији и морала је да води крајње ,промишљену" политику у Европи. Горчаков је и поред тога покушао да нађе компромисно решење, али се Бизмарк са тим није сложио, већ је захтевао да се Русија јасно определи. У Петрограду су убрзо схватили да би "претеран притисак на Пруску" могао да подстакне Бизмарка "на антируски савез са Француском". Тим пре што пруски канцелар то није скривао и у више наврата је дао до знања руском амбасадору Убрилу да ће „он бити принуђен да потражи савез са Француском и тада ће неизбежно поново оживети пољско питање”. Поред тога савез Пруске и Француске могао је да значи ,трајно опстајање” Париског уговора и руска влада је одлучила да не иступа против намера Пруске и Аустрије да ратом реше спор са Данском. Кнез Горчаков не само да није упутио протест већ је одобрио тај корак двеју немачких држава. Руска влада је тиме „платила дуг“ Пруској за указану подршку у време пољског устанка.

Пруска и Аустрија упутиле су јануара 1864. године ултиматум Данској, а када га је она одбила, објавиле су јој рат. Већ у јуну 1864. године дански отпор је био сломљен, краљ Кристијан је морао да уступи сва своја права на Шлезвиг, Холштајн и Лауенбург аустријском цару и пруском краљу. Миром закљученим 30. октобра у Бечу, Шлезвиг се нашао под влашћу Пруске, а Холштајн Аустрије. Пред Пруском је сада стајало отворено питање како се ослободити Аустрије, „Главног супарника у процесу уједињења Немачке". Предмет расправе није била превласт у данским покрајинама, већ у Немачкој. Бизмарк се без имало колебања одлучио за савез са Италијом, која је то била спремна да прихвати са жељом да преотме власт над венецијанском облашћу која се налазила у рукама Аустрије. Русија је покушала да спречи сукоб, почетком 1866. године Александар II иницирао је преговоре са царем Аустрије и краљем Пруске. Горчаков је током преговора схватио да је Бизмарк одлучан да поведе рат против Аустрије, а да је „краљ Виљем I под његовим утицајем”. Русија је страховала да би читав простор могао да постане „трусан“, што је Александар II саопштио пруском генералу Швајницу. „Тај рат би представљао општу беду и од њега би користи имали само револуционарни елементи, непријатељи свих", писао је руски император. Упозорења нису изменила план

\footnotetext{
${ }^{26}$ История внешней политики России, 71.
} 
пруске владе, тим пре што је Француска обећала Пруској да ће остати неутрална. Горчаков је сматрао да Русији не одговара прекомерно јачање Пруске, уз то није одобравао ни Бизмаркове политичке методе. Мислио је да Русија као противтежу Пруској мора одржати добре односе са Француском, на коју је гледао као на „природну савезницу”. Мада је мишљење Наполеона III о промени Париског уговора остало непромењено, Горчаков је сматрао да треба оставити отворена врата за зближење са Француском. Али, он је морао да уважи мишљење цара Александра II, што је значило да у избору будућег савезника Русија предност даје Пруској. ${ }^{27}$

Тако је година 1866. донела нове заплете у међународним односима, конфликт Пруске и Аустрије око хегемоније у Немачком савезу прерастао је у „братоубилачки рат“. Руска влада је заузела неутралну позицију, очекивала је да ће се рат Пруске и Аустрије завршити нерешено. Рат који је почео у јуну 1866. године завршен је поразом аустријске војске код Садове 3. јула. После победе над Данском, Пруска је "учинила први корак ка стварању империје". Победом над Аустријом "учињен је и други корак". Карта Европе, "скројена од стране победника над Наполеоном 1815, изменила се". Пруска је постала одлучујући чинилац у Немачкој, због чега се Наполеон III спремао да „заштити” Аустрију од потпуног пораза. Наполеон је 17. јула обавестио пруског краља Виљема I да се Аустрија обратила Француској са молбом за посредовање у преговорима са Пруском. Бизмарк је пристао на посредовање Француске, али је и сам намеравао да сачува Аустрију као савезника када је показао спремност да са њом ,потпише мир без анексије Одбио је захтев војног врха, који је подржавао краљ Виљем I, да се „иде докраја“ и заузме Беч. На дан битке код Садове, Бизмарк је изјавио: „Са спорним питањима је завршено, сада следи поновно успостављање пријатељских односа са Аустријом“. Услов је био да Аустрија напусти Немачки савез и Холштајн и сагласи се са стварањем Севернонемачког савеза, под вођством Пруске. На тим основама је 26. јула у Николсбургу закључено примирје, а 24. августа у Прагу је потписан и мир. ${ }^{28}$

Пруска се тиме преобразила у озбиљну противтежу западним државама чланицама „ккимске коалиције”, што је добро осетио Александар II који је у Берлин послао поздравни телеграм „са жељом да у међународним односима Русија и Пруска делују споразумно”. Александар је тиме открио пруском краљу „ту скривену мисао“, која се тицала измене одредбе о неутрализацији Црног мора. Краљ Виљем је очигледно то прихватио са одобравањем па је у писму Александру истицао да би задовољење „руских интереса“ могло да веже две државе за „цео један век“. У инструкцији Мантојфелу Бизмарк је писао да ако Русија жели да се ослободи одредби Париског уговора о Црном мору, „Пруска није ни најмање заинтересована за очување његових одредби“. Већ у лето и јесен 1866. године отпочели су преговори између Берлина и Петрограда, када је у руску престоницу стигао пруски генерал Мантојфел. Договорено је да ће Пруска помоћи Русији да се измене одредбе Париског уговора, ако се Петроград не супротстави хегемонији Пруске у

\footnotetext{
${ }^{27}$ С. С. Татищев, нав. дело, 461-462.

28 АВПРИ, ф. Канцелярия, Отчет министра иностранных дел за 1866 г., л. 6-7; История внешней политики России, 72-73; Л. И. Нарочницкая, нав. дело, 78-82; М. Гелер, нав. дело, 127-128.
} 
Севернонемачком савезу. У исто време антируска политика Аустрије и Француске на Балкану „посредно је допринела приближавању” Русије и Пруске. Владе западноевропских држава страховале су да би ослободилачки покрети на Балкану могли довести до стварања независних држава, а тиме и до учвршћивања утицаја Русије. Да би то предупредили, у Салцбургу су 1867. године Наполеон III и Франц Јозеф потписали споразум о очувању целовитости Турске. Када се потом, после свргавања Александра Кузе са румунског престола, поставило питање избора Карла Хоенцолерна за његовог наследника, кнез Горчаков, који је те 1867. године наименован за канцелара, био је уздржан. Горчаков је то разјаснио у писму Игњатијеву, када је истицао „наш унутрашњи положај, реформе које спроводимо, терају нас да одустанемо од учешћа у томе“. Руска влада је, дакле, као и у претходном периоду тежила да избегне нове сукобе на Балкану, о чему Горчаков није остављао недоумице. „У тренутку када ни Русија, ни хришћанско становништво Турске нису спремни за одлучну борбу, сваки покрет на Истоку био би исхитрен и опасан". Тиме је Горчаков осујетио план амбасадора у Цариграду Николаја Игњатијева да у време устанка на Криту Русија подржи општебалкански устанак у Турској који би предводила Србија. Горчаков је опоменуо Игњатијева да заоштравање Источног питања противуречи интересима Русије. ${ }^{29}$

Крај неутрализације Црног мора.

Савез три цара

Завршетак рата Аустрије и Пруске није означио крај сукоба у Европи, већ је наговестио "корените промене у равнотежи снага". После успешних ратова против Данске и Аустрије, Пруска је одлучила да „баци изазов француској хегемонији у Европи”. Русија је морала да се определи, како због чињенице да би победа Француске, сматрали су у Петрограду, учврстила не само положај Наполеона III на континенту, већ и због тога што би то значило нови „импулс кримској коалицији”. Руска влада је сматрала да би тиме био отворен и пут савезу између Француске и Аустрије. У Петрограду су процењивали да Француска у случају успеха не би дала свој пристанак на измену Париског уговора, док је Пруска наговестила спремност да „плати цену” и подржи Русију у намери да измени одредбе о неутрализацији Црног мора. Горчаков је са задовољством могао да констатује да су „све државе усмерене сада ка Западу" и да је нужно искористити ту околност ради решења „за нас животно важних интереса на Истоку“. У априлу 1867. године Горчаков је у циљу подршке Пруској изјавио да је Русија спремна да, уколико дође до савеза Француске и Аустрије, створи Бечу „озбиљне неприлике”. Канцелар Бизмарк је тиме могао да буде задовољан. После тога Бизмарк је упутио у Петроград депешу, у којој је наговестио да би „Пруска могла подржати жеље и намере Русије” у односу на Париски уговор. Јуна 1867. године Александар II и Горчаков посетили су Светску изложбу у Паризу, „чији бљесак није могао да сакрије пукотине у здању империјалне Француске“, са намером да отпочну преговоре са Наполеоном III, али

\footnotetext{
${ }^{29}$ Н. С. Кинямина, нав. дело, 51-53.
} 
се сусрет завршио неуспешно. Наполеон III је одбио разговор о измени одредби о неутрализацији Црног мора, што је указивало да Русија не може да рачуна на подршку Француске. Горчакова је то навело да закључи, да је „озбиљан и постојан споразум с Пруском најбоља комбинација". ${ }^{30}$

После повратка из Париза цар и Горчаков почели су да делују много одлучније у правцу зближења са Пруском. Бизмарк је истовремено чинио све да убеди Русију у предности савеза са Пруском. У фебруару 1868. године Александар II је у писму Виљему I изразио жељу да са Пруском „продужи споразум” сачињен још за „владавине Александра I и Фридриха Виљема III”. Био је то сигнал за отпочињање преговора две државе, чиме је Русија охрабрена да за измену Париског уговора о неутралности Црног мора подршку тражи од Пруске. Бизмарк је обећао Горчакову да ће "подржати главни захтев Русије у замену за благонаклону неутралност у случају рата са Француском и обавезу да паралише главне војне снаге Аустрије". Сагласност канцелара око кључних питања омогућила је да већ марта 1868. године буде сачињен начелни споразума две државе. Споразумом је предвиђено да у случају пруско-француског рата, Русија сачува неутралност и "демонстративно упути на границе Аустрије армију од 100.000 војника". Пруска је заузврат званично потврдила раније обећање да ће подржати Русију у напорима за промену одредбе Париског уговора о Црном мору. Као и раније, целокупна спољна политика владе у Петрограду била је посвећена том циљу, док је Бизмарк боље од Наполеона знао како да се тиме окористи. У августу 1868. године Бизмарк је саопштио Петрограду да Русија може да рачуна на подршку Пруске у промени Париског уговора. „Ми ћемо радо урадити за њу све што је могуће”, изјавио је канцелар. $^{31}$

Прецењујући своју војну снагу, министар Лебеф је изјавио да пруска армија „не постоји и да је он не признаје“; Француска је 19. јула 1870. године објавила рат Пруској. Три дана касније Русија је обелоданила Декларащију о неутралности. „Његово императорско величанство одлучно је да очува строгу неутралност у односу на ратујуће државе, али само до тренутка док рат не угрози интересе Русије.“ У Декларацији је исто тако истакнуто да је „царска влада увек спремна да пружи најискренију помоћ свакој тежњи којој је циљ да ограничи размере ратних збивања, да скрати њихово трајање и врати Европи благодети мира“. Из Петрограда је потом упућена порука у Беч и Париз да ће, ако Аустроугарска уђе у рат, Русија следити њен пример. Посланику Аустроугарске у Петрограду саопштио је Горчаков да „ако Аустрија приступи мобилизацији, то ће урадити и Русија, ако она узме учешће у рату ми ћемо бити у стању да заштитимо сопствене интересе“. Беч је после тога заузео неутралну позицију, као и Велика Британија и Италија. Пруска армија се на бојишту показала супериорнијом. После катастрофе код Седана 2. септембра 1870. године, када је заједно са војском заробљен и цар Наполеон III, Француска је

\footnotetext{
${ }^{30}$ АВПРИ, ф. Канцелярия, Отчет министра иностранных дел за 1866 г. и 1867 г., лл. 12-15 и 95-96; История внешней политики России, 75.

${ }^{31}$ С. С. Татищев, нав. дело, 474-475; Л. М. Шнеерсон, нав. дело, 101-122; С. В. Оболенская, Франкопруская война и общественное мнение Германии и России, Москва 1977, 58-73.
} 
фактички била поражена. Опште незадовољство у Француској довело је до формирања владе Народне одбране, свргавања Наполеона и проглашења републике 4. септембра 1870. године. У Петрограду "нису очекивали тако брз пораз Француске" и били су "непријатно изненађени претензијама Пруске на француске покрајине Алзас и Лотарингију". Цар Александар је писао пруском краљу сугеришући му да не намеће Француској понижавајући мир, али је Виљем I одговорио да му ,јавно мњење неће дозволити да се одрекне анексије“. Када је потом председник француске републике Тијер посетио Петроград, Горчаков му је саопштио да „треба имати срчаности и закључити мир“. ${ }^{32}$

Заинтересованост за подршку Берлина у погледу Париског уговора, није дозвољавала цару Александру II да иступи против захтева Пруске. Тако је рат Пруске и Француске указао Петрограду на прави тренутак за измену чланова Париског уговора, који су ограничавали његова права у Црном мору. После Седана Горчаков је сматрао да је наступио тренутак да „спере љагу која је остала на образу Русије још од Кримског рата". Горчаков је потом саопштио цару да је време да се постави питање о „оправданости захтева” Русије. Предлог Горчакова разматран је 27. октобра 1870. године на заседању Савета министара, али није било јединственог мишљења, мада је канцелар Горчаков сматрао да ће се противљење европских држава свести само на ,рат на хартији”. Руски министар је тврдио да је прилика крајње повољна јер је Француска као једна од гарантних сила Париског уговора „била оборена”, а без ње Аустроугарска "није смела да ризикује да се супротстави Русији". Услед промењене равнотеже снага, "било је мало вероватно да ће против Русије иступити Турска". Преостала је само Велика Британија, али она се сада налазила у „исвесној изолацији”. Стога је било неопходно да Русија делује брзо, док је за Пруску њена подршка још била од значаја. ${ }^{33}$

Горчаков је учинио први корак, који је наговестио намере Русије у погледу даљег извршења Париског уговора. Руски канцелар је 31. октобра 1870. године упутио циркулар дипломатама акредитованим у престоницама држава потписница Париског уговора. У циркулару је подсећао да је Русија доследно испуњавала чланове уговора када су то чиниле и друге државе, при чему је истицао да у измењеним околностима она „не може да допусти да уговор, нарушен у многим појединим и општим члановима, остане обавезујући у оним члановима који се тичу њених интереса". Тако је уговор довео Русију у неравноправан и опасан положај, због чега се руска влада, упозоравао је Горчаков, више не сматра обавезном на поштовање одредбе која ограничава њена суверена права на Црном мору. Стога је захтевао од руских дипломатских представника да владама код којих су акредитовани разјасне да је циљ његовог демарша само да заштити безбедност Русије, уз обећање да ће Русија све остале чланове Париског уговора „постојано испуњавати”, што је значило да неће „отварати ни Источно питање“. То је учињено

\footnotetext{
32 Л. И. Нарочницкая, нав. дело, 71-96; Л. М. Шнеерсон, Франко-пруская война и Россия, Минск 1976, 91-100.

${ }^{33}$ АВПРИ, ф. Канцелярия, Отчет министра иностранных дел за 1870 гг., л. 24-25; С. К. Бушуев, $A . M$. Горчаков, Москва 1961, 91-98; История внешней политики России, 77.
} 
у тренутку капитулације француске армије у Мецу, што је "потврдило да је Француска била елиминисана као фактор супротстављања Русији". Преостале су Велика Британија и Аустроугарска које су се одлучно противиле намери Русије, али нису имале реалне могућноси да то спрече. Сједињене Америчке Државе подржале су Русију, међутим, од највеће важности је била подршка Пруске. Бизмарк је касније тврдио да је 1870. године подржао Русију, због тога што је забрана слободне пловидбе у "сопственом мору за њу била неприхватљива“. „Ми смо радо стали на страну Русије... да би је ослободили ограничења наметнутих Париским уговором. Она су била неприродна, а забрана пловидбе крај сопствених морских обала била је за такву државу као што је Русија неодржива на дуже време, јер је била понижавајућа“. Прави смисао Бизмарк је открио касније када је рекао да је за Немачку пожељније да се Русија окрене на исток него на запад. ${ }^{34}$

У Европи је циркулар био изненађење. Енглеско Министарство спољних послова саопштило је да руска влада не би требало да иступи са једностраном изјавом, већ да је неопходно да се обрати и другим државама потписницама Париског уговора са предлогом за измену његових одредби. Канцелар Бизмарк, иако незадовољан, како је говорио „неправовременим” иступом Горчакова, био је одлучан да докраја испуни обећање дато Русији. Истога мишљења је био и краљ Виљем, када је свом саветнику Швајницу рекао да „сама по себи Декларащија је сасвим исправна“. Пруска је после тога предложила сазив конференције држава потписница Париског уговора, са циљем да се размотре питања која је поставио Горчаков у циркулару. Велика Британија и Аустроугарска сагласиле су се са предлогом, ,под условом да резултати конференције не буду одлучени раније” и да у њеном раду учествују све државе потписнице Париског уговора. Русија је прихватила одржавање конференције, али под условом да она само санкционише одлуку руске владе. Влада и цар су пристали, рачунали су на Бизмаркову подршку и повољне међународне околности. ${ }^{35}$

Лондонска конференција европских држава, сазвана на иницијативу Бизмарка, за коју је Горчаков сматрао да треба да буде „кратка и да има чисто практични смисао“, одржана је од 17. јануара до 13. марта 1871. године. Велику Британију је на конференцији представљао министар спољних послова Гренвил, док су "друге земље заступали дипломатски представници акредитовани у Лондону". Задатак руског посланика Брунова био је да одлуку Горчакова из цирлукара „учини међународном". Уз то, Горчаков је у инструкцији Брунову саветовао да буде „умерен и опрезан, да пажњу учесника конференције усмери на погубност Париског уговора за унутрашњи развитак Русије, њену пољопривреду, индустрију, безбедност“. Најзначајније дискусије вођене су о условима регулисања пловидбе мореузима. Велика Британија и Аустроугарска прихватиле су на крају споразум о измени одредбе Париског уговора о неутрализацији Црног мора. Режим пловидбе мореузима претрпео је тиме неке "за Русију не сасвим прихватљиве измене". Султану је дато право да регулише режим пловидбе мореузима и „у миру у корист

\footnotetext{
${ }^{34}$ С. С. Татищев, нав. дело, 478-479.

${ }^{35}$ История внешней политики России,78.
} 
војних бродова пријатељских и савезничких држава", ако Турска "нађе да је то неопходно, да би осигурала испуњење одредбе Париског уговора". "Тај члан погоршао је положај Русије у њеним одбрамбеним плановима у односу на конвенцију из 1841. године", која је одређивала да у време мира мореузи буду затворени за војне бродове, осим лаких, свих држава. Потом је уследило потписивање конвенције између Русије и Турске, којом је била анулирана конвенција из 1856. године. Измена одредбе о неутрализацији Црног мора представљала је лични успех Горчакова, који је умео да искористи међународне околности за „избављање Русије од најтежих услова Париског уговора”. Русија је поново успоставила своја суверена права на Црном мору и тиме повратила престиж велике силе. Лондонска конференција се тако сагласила са изменом свих дотадашњих ограничења, што је значило да је Русија могла да у Црном мору држи флоту и гради утврђења. Била је то "дипломатска победа без рата", важна за њен положај у Европи. Током петнаест година, колико је Русији требало да анулира одредбе Париског уговора, прилике у Европи су се промениле, „Немачка је постала империја". Удео Русије у томе цар Виљем није скривао, што је и признао у писму цару Александру: „, Никада Пруска неће заборавити да је она вама дужна за то што рат (против Француске) није добио шире размере. Да Вас за то благослови Господ!“. ${ }^{36}$

Уједињење Немачке, проглашено у Версају 18. јануара 1871. године, када се „Југ који је дуго задржавао неутралну позицију ујединио са Севером“, довело је до "новог распореда снага на континенту". Русија је сада на својим границама имала моћног суседа, због чега јој даље слабљење Француске није одговарало. У руској јавности чули су се гласови за поновно зближење са Француском. Тог мишљења био је и Горчаков, који је схватао значај Француске као противтеже обновљеној Немачкој. „Нама је потребна јака Француска”, изјавио је Горчаков, мада је француска влада била свесна тадашње блискости ,петроградског и берлинског двора". Министар спољних послова Жил Фавр сматрао је да Француска у том тренутку не може ништа да очекује од Русије, али да ће се пре или касније показати да се „нова немачка империја више не може ширити, а да при томе не угрози безбедност Русије". Русија је у међувремену отпочела са активном политиком у Централној Азији, што је заоштрило њене односе са Великом Британијом. Због тога joj је сада био потребан чврст ослонац у Европи, који је једино могла да нађе у Немачкој. Руска влада је рачунала да ће уз помоћ Немачке онемогућити експанзију Аустроугарске на Балкан, где је после пораза у рату 1866. године она усмерила своју активност. Министар спољних послова Аустроугарске гроф Андраши такође је тражио подршку Немачке против Русије, у којој је видео главног противника. Бизмарк је у исто време подстицао активност Аустроугарске на Балкану, на тај начин желео је да одвуче њену пажњу од Централне Европе. Али он није хтео да Аустроугарску сасвим удаљи од Немачке, у будућности јој је наменио улогу савезника. У исто време био је спреман на споразум са Русијом, да би онемогућио руско приближавање Француској. По мишљењу руског дипломате грофа Петра

\footnotetext{
${ }^{36}$ Сборник договоров России с другими государствами 1856-1917, 107-110; М. Гелер, нав. дело, 133.
} 
Шувалова, Бизмарка је прогонио „кошмар коалиције“. Тај „кошмар“ није случајно нарушавао спокојство немачког канцелара, међународни односи почетком осамдесетих година давали су основа за могуће зближавање Русије са Аустроугарском и Француском. После 1871. године Бизмарк је чинио све да очува постигнуто, при чему је „показао зрелу политичку мудрост“. Аустроугарска је за њега била „идеалан партнер", стога што је савез са њом гарантовао немачку превласт у Средњој Европи.

Руска влада је са пажњом пратила односе Берлина и Беча, рачунала је са Немачком као "пожељним савезником", а у исто време и као посредником у разрешењу спорних питања са Аустроугарском. Приближавање Аустроугарске и Немачке требало је да буде озваничено у септембру 1872. године, када је планирана посета цара Франца Јозефа Берлину. Да би предупредио стварање двојног савеза, Александар II је у писму Виљему I дао до знања да жели да учествује у сусрету двојице монарха. Руски цар је страховао од могућности закључења аустро-немачког савеза, па је цар Виљем I, по савету Бизмарка, пристао да састанку присуствује и руски цар. Александар II је, стога, почетком септембра 1872. године отпутовао у Берлин, где је Виљем I позвао и цара Франца Јозефа. Преговори у Берлину довели су до приближавања ставова Горчакова и Андрашија. У погледу Балкана постигнут је договор о подршци status quo-a, споразум је уз то допуњен и заједничком изјавом „да се ниједна од страна неће мешати у унутрашње послове Турске“. Бизмарк је подржао договор па је приликом сусрета са Горчаковом изјавио да ће прихватити оне акције на Балкану које усагласе Петроград и Беч. Касније је Горчаков писао да у разговору са Бизмарком није било ничег новог, осим жеље за што „чвршћим јединством између Русије и Аустрије“. Тиме се Бизмаркова интервенција свела, како је писао Горчаков, ,само... на што веће јединство Русије и Аустрије”. Бизмарк je, наиме, планирао савез са недавно побеђеном Аустријом, а намеравао је да у нову алијансу увуче и Русију. ${ }^{37}$

Сусрет у Берлину поставио је добре основе за постизање коначног споразума три државе. Почетком маја 1873. године цар Виљем I је у пратњи Бизмарка и фелдмаршала Молткеа стигао у посету Петрограду. Резултат сусрета немачког и руског цара било је закључење војне конвенције, коју су 6. маја 1873. године потписали начелници генералштабова Берг и Молтке. Обе стране су прихватиле обавезу да уколико би нека од европских држава напала једну од потписница конвенције, друга би ,у најкраћем року ангажовала армију од 200.000 људи”. Конвенција и поред тога „није садржала ничег непријатељског према било којој нацији, или пак влади“. Међутим, Бизмарк је желео да се споразуму прикључи и Беч, тврдио је да конвенција „неће имати снагу ако њој не приступи Аустрија“. У јуну 1873. године Александар II је у пратњи Горчакова посетио Беч, у намери да убеди Франца Јозефа да приступи руско-немачкој конвенцији. Током преговора две државе су се сагласиле да у случају угрожавања европског мира претходно постигну међусобни споразум о „начину заједничког деловања”. У случају, пак, да се појави

\footnotetext{
${ }^{37}$ АВПРИ, ф. Канцелярия, Отчет министра иностранных дел за 1872. г., л. 26об-27; М. Гелер, нав. дело, $133-134$.
} 
неопходност прибегавања сили, предвиђено је да се представници двеју држава састану да би конкретизовали обавезе о међусобној подршци. Две државе би само у том случају прибегле закључењу војне конвенције. Споразум, ради „учвршћивања мира“, потписан је 6. јуна 1873. године у дворцу Шенбрун. Била је то политичка, а не војна конвенција, пошто аустријска влада није желела да јој да̂ обавезујући карактер. Али цар Александар II је био задовољан, што је потврдио у писму Виљему I. „Ја сам добио, не без великог труда, резултат, који смо ми желели..., ни цар, ни Андраши нису хтели да се сагласе да споразум добије форму војне конвенције, једнаку оној која је била потписана од стране двојице наших маршала““. ${ }^{38}$

Коначно, 23. октобра 1873. године конвенцију је потписао и немачки цар приликом посете Бечу, чиме је створен „консултативни пакт између три државе који је Европа назвала Савез три цара“. То и није био уговор о савезу већ споразум три конзервативне државе, у коме је свака од његових потписница следила сопствене спољнополитичке циљеве. У пракси формални уговор цареви нису закључили, ограничили су се само на измену нота о три проблема: очувања постојећих граница у Европи, Источном питању и предузимању заједничких мера против револуције „која је могла да угрози све три државе". Споразум је потписан, али су супротности међу државама, посебно између Русије и Аустроугарске, остале. Свака од њих је тежила да не допусти другој превласт на Балкану и свака од њих је рачунала да ће за своју политику придобити Немачку. Са друге стране, Немачка је желела да искористи супротности између Русије и Аустроугарске за добијање одрешених руку у западној Европи. Немачка је тежила да стекне доминацију на континенту, да коначно као супарника елиминише Француску.

Цар Александар II и канцелар Горчаков, који је формално водио руску спољну политику, „видели су у могућности преображаја Немачке у моћну империју опасност за Русију". Али, Александар II је донео коначну одлуку, јер је у империји свога ујака Виљема I видео верног савезника, не само у борби против револуције већ и у решењу Источног питања. Јачање Немачке и њен преображај у империју имало је за последицу изливе антинемачких осећања од стране представника различитих друштвених кругова Русије. Славенофили су упорно понављали да је Немачка главни непријатељ Словена. Додуше, то се пре свега тицало Аустрије, али јачање моћи Пруске почело је "озбиљно узнемиравати и дипломате и војнике“. Публициста Михаил Катков који је играо важну улогу у јавном и политичком животу, „до њега Русија није знала за публицисту, који је имао такав утицај на политику земље", сматрао је да је за Русију опасан савез са Немачком, коју је окарактерисао као „непријатеља Словена”. Ништа мање емотивно изражавао је своје погледе и генерал Михаил Скобељев, прослављен у ратовима у Централној Азији и са Турском. За генерала Скобељева све је било јасно: „Да! Странац је код нас свуда. Рука његова присутна је свуда. Ми смо играчка његове политике, жртве његове интриге, робови његове силе... и желите ли да сазнате од мене ко је тај

\footnotetext{
${ }^{38}$ С. С. Татищев, нав. дело, 494-499; Сборник договоров России с другими государствами 1856-1917, 124, 126-127; Л. М. Шнеерсон, На перелутье европейской политики. Австро-русско-германские отношения (1871-1875), Минск 1984, 91-107.
} 
странац,... то је интригант, то је непријатељ Русије и Словена, ја ћу вам рећи то је Немац. Понављам вам и молим вас да не заборавите, наш непријатељ је Немац" ${ }^{39}$

Русији је уговор са Немачком и Аустроугарском осигурао безбедност западних граница и тиме олакшао њену политику у Централној Азији. Бизмаркова намера да, услед заузетости Русије „источним пословима”, успостави хегемонију Немачке у Европи показала се илузорном. Руска влада је добро схватила опасност од хегемоније Немачке на континенту и стога није желела да је подржи. Посебно је то дошло до изражаја почетком 1872. године када је Бизмарк, у настојању да још више ослаби Француску, отпочео са политиком изазивања новог конфликта. Повод за такав Бизмарков иступ било је објављивање, током 1872. године, закона о општој војној обавези, којим је Француска желела да обнови своју војску. Француском министру спољних послова Деказу ,једину наду представљало је тражење покровитељства руског цара“. У разговору са Лефлоом, који је потом уследио, Горчаков је стао на страну Француске. „Ја сам Вам већ то рекао и сада то понављам, нама је потребна снажна Француска". Русија је тиме јасно ставила до знања да не жели даље слабљење Француске и да не подржава Немачку. Захваљујући ставу Русије, криза је тада превазиђена, али односи Берлина и Париза поново су заоштрени 1874. године. Француски посланик у Петрограду Лефло указао је Горчакову на опасност која његовој земљи прети од Немачке. Министар спољних послова Деказ тражио је заштиту од Петрограда. Горчаков је обећао да ће Русија заштитити Француску. Готово идентичан одговор добио је француски дипломата и од цара Александра II. У пролеће 1875. године онеспокојена брзим опоравком Француске, Немачка је отпочела са припрема за нови рат, да не би, како се изразио Бизмарк, „болесна Француска оздравила”. Руски канцелар Горчаков био је категорички против давања пристанка за превентивни рат против Француске, коју је од њега тражио Бизмарк. Рат је на тај начин избегнут, али је Бизмарк за свој неуспех сву кривицу бацао на Горчакова, када је изјавио да је ,,једини гарант постојаности руске сарадње са Немачком личност цара". ${ }^{40}$

Бизмарк је овога пута рачунао да ће због заузетости Русије у Централној Азији, у обрачуну са Француском имати пуну слободу деловања. У фебруару 1875. године затражио је, посредством свог дипломатског изасланика Радовица, од руске владе пријатељску неутралност у случају новог сукоба са Француском, а заузврат јој је обећао сарадњу на Истоку. Бизмарк је, дакле, за подршку Русији на Истоку тражио да она напусти Француску, али му је одговорено да Петроград „тамо нема ништа у виду осим спокојства и општега мира". Истовремено су француском посланику у Петрограду и цар и канцелар саопштили да ће пружити његовој земљи дипломатску подршку. Цар Александар је француском посланику још рекао да ће Немачка, ако иступи без стварног повода, „преузети на себе велики ризик”. Александар II је свој став потврдио и приликом пропутовања кроз Берлин у мају 1875. године, када се изјаснио против новог немачко-француског рата. После тога Бизмарк је био принуђен да се повуче, а цару Александру II саопштено је „да

\footnotetext{
${ }^{39}$ М. Гелер, нав. дело, 126, 135-136.

${ }^{40}$ История внешней политики России, 82-83; Bismark, нав. дело, 516, 528.
} 
никакво агресивно деловање против Француске није планирано”. Одговорност за ратне припреме канцелар је пребацио на генерале, за које је рекао да се „ништа нису разумели у политику”. Русија је тиме отклонила Бизмаркову намеру „превентивног" рата против Француске. Пошто је коначно отклоњена опасност од рата, Горчаков је руским дипломатским представницима у европским престоницама упутио лаконску поруку: „Од сада је мир обезбеђен”. „Војна узбуна” 1875. године допринела је хлађењу односа Русије и Немачке, али није довела до распада Савеза три цара јер су обе стране биле заинтересоване за очување првобитног споразума. Избијање Источне кризе 1875. године показало је сву дубину противречности и сву „трошност” Савеза три цара. Када је Горчакову пошло за руком да убеди Александра II у опасност која потенцијално прети од Немачке, променила се и руска политика. Кнез Бизмарк није скривао своје разочарење и упозорио је Горчакова: „Кажем вам отворено: ја сам добар пријатељ мојим пријатељима и непријатељ мојих непријатеља". Непријатељ Бизмарка био је Горчаков а потенцијални савезник цар Александар II. ${ }^{41}$

Еволуција спољне политике Русије после Кримског рата била је условљена како неопходношћу реформи у самој земљи тако и измењеним околностима у међународним односима. Русија је морала да „обезбеди предах после изгубљеног рата за спровођење унутрашњих реформи", али у исто време морала је да тражи и начин да изађе из „опасног и понижавајућег положаја” у који ју је довео Париски мировни уговор. Било је потребно да земља изађе из међународне изолације, у којој се нашла пред антируском „кримском коалицијом” европских држава.

Руска дипломатија је остварење својих задатака у Европи постигла прво путем зближења са Француском, а када се то показало неуспешним, са Пруском. Први корак у зближењу са Пруском учињен је у време устанка у Пољској 1863. године, да би 1871. године, после пораза Француске, Русија искористила погодан тренутак и дипломатским средствима, уз подршку Пруске, добила измену чланова Париског уговора који су ограничавали њена права у Црном мору.

Тај успех био је такође „купљен" великом ценом, пристанком на уједињење Немачке под вођством Пруске, што је суштински изменило прилике у Европи, а самим тим и положај Русије. Поставило се после тога питања осигурања западних граница земље, настала је потреба за тражењем нових савезника ради обезбеђења позиције земље у међународним односима. Прво је нађен излаз у зближавању са Немачком и Аустроугарском, у форми Савеза три цара. Али, тај „консултативни пакт“ конзервативних држава показао се недовољно постојаним, због противречности интереса његових чланица у Европи и на Балкану.

41 С. С. Татищев, нав. дело, 505-509; Ю. В. Борисов, Русско-франиуские отношения после Франкфуртского мира 1871-1875 г2., Москва 1951, 218-253; В. М. Хвостов, История дипломатии, Т. II, Москва 1974, 51; М. Гелер, нав. дело, 137. 


\section{Извори и литература:}

Архив внешней политики Российской империи, ф. Канцелярия, Отчет министра иностранных дел.

Bismark, Gedanken und Erinnerungen, Stuttgart-Berlin 1928.

Борисов, Ю. В., Русско-франиуские отношения после Франкфуртского мира 1871-1875 г2., Москва 1951.

Бушуев, С. К., А. М. Горчаков, Москва 1961.

Гелер, М., История Российской империи, Т. ІІІ, Москва 1997.

История внешней политики России. Вторая половина ХІХ века, Москва 1997.

Кинямина, Н. С., Внешняя политика России второй половины ХІХ в., Москва 1974.

Международные отношения на Балканах 1856-1878 г2., Москва 1986.

Mosse, E., The Rise and Fall of Grimean system 1855-1871, London 1963.

Нарочницкая, К. В., Россия и отмена нейтрализаииий Ченого моря 1856-1871 г2., Москва 1989.

Нарочницкая, Л. И., Россия и войны Пруссии в 60-х годах за объединение Германии „сверху“, Москва 1960.

Нарочницкий, А. Л., Международные отношения и внешняя политика России от Парижсккого (1856 г.) до Франкфуртского мира, Москва 1946.

Оболенская, С. В., Франко-пруская война и общественное мнение Германии и России, Москва 1977.

Рувененков, В. Т., Польское восстание 1863 г. и европейская дипломатия, Москва-Ленинград 1957.

Рыжова, Р. И., Сближение России с Франции после Кримской войны и русско-франиузкий договор 3. марта 1859 г. Учены записки МГУ им. В. П. Потемкина, Т. XXVIII, Вып. 4, Москва 1959.

Сборник договоров России с другими государствами 1856-1917 гг., Москва 1956.

Татищев, С. С., Император Александар II. Его жизнь и иарствование, Москва 2006.

Хвостов, В. М., История дипломатии, Т. ІІ, Москва 1974.

Хитрова, Н. И., Триумф А. М. Горчакова, Отмена нейтрализации Черного моря, у Российская дипломатия в портретах, Москва 1992.

Шнеерсон, Л. М., На перелутье европейской политики. Австро-русско-германские отношения (1871-1875), Минск 1984.

Шнеерсон, Л. М., Франко-пруская война и Россия, Минск 1976. 


\title{
FOREIGN POLICY OF RUSSIA FROM THE CRIMEAN WAR TO THE GREAT EASTERN CRISIS (1856-1875)
}

\begin{abstract}
Summary
The evolution of the foreign policy of Russia after the Crimean war was conditioned by the necessity to reform the country, as well as by changed circumstances in the international relations. Russia had to 'have a break after the lost war in order to implement internal reforms'. At the same time, Russia had to find a way out of 'dangerous and degrading position' to which it was brought by the Paris Peace Treaty. It was necessary to took the country out of international isolation, which it faced before the antiRussian, ‘Crimean coalition’ of the European countries.

Russian diplomacy managed to implement its tasks in Europe primarily through rapprochement with France, and when this proved unsuccessful, it reproached Prussia. The first step in the rapprochement with Prussia was made at the time of the uprising in Poland in 1863, and in 1871, after the defeat of France, Russia used the right moment and diplomatic means, with the support of Prussia, to change Articles of the Paris Treaty which had limited its rights in the Black Sea.

This success was also 'purchased' with high price, by agreeing to the unification of Germany under Prussian leadership, what substantially changed situation in Europe, and thus the position of Russia as well. After that, there were raised issues related to the Western borders of the country, and there was emerged a need to find new allies to ensure the country's position in the international relations. Primarily, the way out was found in the rapprochement with Germany and Austria-Hungary, in the form of the Union of Three Emperors. However, this 'consultative pact' of conservative countries proved to be insufficiently stable, due to the contradiction of interests among its members in Europe and the Balkans.
\end{abstract}

Keywords: Russia, France, Prussia, the Paris Congress, the Polish uprising, End of neutrality of the Black Sea, the Union of Three Emperors 